\title{
Knowledge of Patient's Health Rights among Medical Students in Jeddah, Saudi Arabia 2020 - A Cross Sectional Study
}

Heba K. Alshaeri ( $\square$ hkalshaeri@fcms.edu.sa )

Fakeeh College for Medical Sciences

Ali S. Al Qarni

Ibn Sina National College (ISNC)

Shahad A. Alharbi

Jeddah University

Safia M. El-Qaisi

Fakeeh College for Medical Sciences

Sarah A. Saif

Fakeeh College for Medical Sciences

Muhannad H. Bin Sawad

King Saud bin Abdulaziz University for Health Sciences

Maram M . Alharbi

Batterjee Medical College

Zuhair S. Natto

King Abdulaziz University

Research Article

Keywords: Caesarean Section, Cancer Patients, Medical Students, Public Health Rights, Saudi Arabia, Special Needs.

Posted Date: December 15th, 2020

DOI: https://doi.org/10.21203/rs.3.rs-114983/v1

License: @) (1) This work is licensed under a Creative Commons Attribution 4.0 International License. Read Full License 


\section{Abstract}

Background: Saudi Arabia aims to affirm the basic human rights for all its citizens. The medical students need to be aware about globally recognized rights in their study and career. Only few studies have measured the knowledge of medical students about public health rights (PBR) in Saudi Arabia. The present study aims to assess the current knowledge of medical students in Jeddah, Saudi Arabia concerning health empowerment issues and health rights.

Methods: Descriptive cross-sectional study was conducted at Jeddah, Saudi Arabia among the medical students of Ibn Sina National College (ISNC), Batterjee Medical College (BMC), King Abdul-Aziz University (KAU) and King Saud bin Abdul-Aziz University (KSAUHS) Jeddah branch, between July and August 2020. Questionnaire was used to collect demographic data, along with knowledge of the rights of female patients, laws and rights of patients with disabilities, special needs and senility, reproductive health rights, and health rights of cancer patients. The data were analyzed using statistical package of social science (SPSS) version 25 .

Results: Of the 393 participants, $58.3 \%$ were females and $41.7 \%$ were males. Regarding consent, $72.3 \%$ and $65.1 \%$ of the participants responded that a male guardian was not required to give consent for hospital admission and discharge, respectively, and only $46.1 \%$ knew that a female patient could provide consent for a caesarean section. Only $51.7 \%$ of the students were aware about Saudi Arabian health rights including the disabled individuals; while, $44.0 \%$ did not know. About half (53.2\%) knew that that special needs patients have health rights, and $25.2 \%$ believed that abortion is never allowed in Islam. Concerning the woman's right to attain contraception, $51.1 \%$ stated that the consent was not required; while, $25.7 \%$ responded that consent from a male guardian/partner is first required. Approximately half (49.6\%) were aware that cancer patients have the right to free medical treatment, and $52.9 \%$ knew that cancer patients have the right to free surgical treatment.

Conclusions: The knowledge of medical students regarding health rights of certain patient populations was not satisfactory in Saudi Arabia, which highlights the importance of health rights education in medical school.

Trial registration: 95/IRB/2020

\section{Background}

Human rights, the fundamental standards of mankind reflect a common understanding towards human values, without considering human differences [1]. Health is considered as a major part of human rights and standard of quality of life [2]. The World Health Organization (WHO) referred health as not only the absence of disease or inability, but as a condition of complete physical, intellectual, and social well-being [3]. The conception of patient's right was expanded based on the standards. The rights vary from country to country depending upon widespread cultural and social norms in each country, and the standard to maintain the dignity and equality among the patients $[4,5]$.

The World Federation for Medical Education (WFME) establishes the need to balance the academic and behavioral skills of medical students [6]. In 2006, the Ministry of Health (MOH) in Saudi Arabia issued the Patient Bills Rights (PBR) and stated about all the required rights to health care to highlight the need medical care for every citizen. These rights to health care are available in their policy, procedure manual, and regular circulars [7]. Regarding patients' values and preferences of treatment, the sustainable development purposes included many purposes and targets for promoting health. For instance, it includes incorporating patient priorities and preferences into their healthcare to enhance desirable proximal outcomes linked to communication. Appropriate understanding of patients towards care ease the impact of drawbacks of this disease and may support physicians in decision-making [8, 9].

Declaration of patient's rights is still vague concept for health care workers and patients; although, nowadays there are many declarations regarding this aspect across the world [10]. Medical students as well as health care workers need to understand and accommodate the patient's health rights to insure a healthy and high-quality lifestyle for human beings and achieve professional objectives [11, 12]. One of the previous studies evaluated the extent of knowledge medical students, health care workers, and patients about PBR, which showed that $39.7 \%$ of female patients had no such right to make the decision and $45.7 \%$ had no knowledge. Moreover, $32.6 \%$ and $42.3 \%$ of the respondents believed that a male guardian was required to give an approval for women's medical treatment and surgery, respectively [7]. Another cross-sectional study done in Tabuk showed that majority of participants (98.5\%) notified about diagnosis and treatments updates in understandable language and $95.1 \%$ knew that therapeutic group ought to report any savagery against children to the specialist [3]. Considering the notable shortage of studies that measure the knowledge of medical students about PBR Saudi Arabia, medical students should be introduced to these globally recognized rights as early as possible in their study and career. The aim of this study was to assess the current knowledge of medical students in Jeddah, Saudi Arabia concerning health empowerment issues and health rights.

\section{Methods}

\section{Study Design and Setting}

This descriptive cross-sectional study was conducted at Jeddah, Saudi Arabia among the medical students of Ibn Sina National College (ISNC), Batterjee Medical College (BMC), King Abdul-Aziz University (KAU) and King Saud bin Abdul-Aziz University (KSAUHS) Jeddah branch, from July to August 2020.

\section{Ethical Approval}

The approval was obtaining from Dr. Soliman Fakeeh Hospital Scientific Research Review Committee (DSFH IRB).

\section{Study Sample}


The targeted sample was selected from $2^{\text {nd }}$ year internship medical students by random sample selection. The students who had a previous bachelor degree in the medical field, were excluded.

\section{Data Collection}

A validated questionnaire was used from a previous study [7] for the purpose of data collection. The questions were divided into 5 sections with total of 24 questions survey sections as following:

- First section was about demographic data: gender, academic year, college/ university, and previous bachelor's degree (4 questions)

- Second section was related to the knowledge of the rights of female patients (yes, no or I do not know) (5 questions)

- Third section was about the knowledge of the laws and rights of patients with disabilities, special needs and senility (yes, no, or I do not know) (3 questions)

- Fourth section was about the knowledge of the reproductive health rights (yes, no or I do not know) (5 questions)

- The last section was about the knowledge of the health rights of cancer patients (yes, no or I do not know) (7 questions)

\section{Data Analysis}

All data were analyzed using statistical package of social science (SPSS) version 25. Any significant differences were assessed by frequency, means, and chi square test. Data were considered significantly different when $p<0.05$.

\section{Results}

A total of 393 participants were recruited in this study, among which $58.3 \%$ were females and $41.7 \%$ were males. Further, $21.8 \%$ of the participants were from KAU, 43.5\% were from ISNC, $21.8 \%$ were from BMC, and 12.7\% from KSAUHS. The total mean age of the participants was $22.22 \pm 1.86$ (Table 1 ).

The results of assessing the knowledge toward the rights of female patients showed that $72.3 \%$ and $65.1 \%$ of the participants responded that a male guardian was not required to give consent for hospital admission and discharge, respectively. Similarly, $71.2 \%$ and $60.6 \%$ of the participants responded correctly that hospital rules do not need female patients to acquire a male guardian's consent for medical treatment and surgery, respectively. However, a caesarean section showed that only $46.1 \%$ of the medical students had knowledge that women can make their decision for herself and provide consent; whereas, $21.6 \%$ believed that female patients did not have this right, and $32.3 \%$ did not know about this at all (Table 2).

Table 3 shows the analysis of knowledge of medical students towards the law and rights of patient with disabilities, special needs and senility. It shows that only $51.7 \%$ of the students knew that Saudi Arabian health rights law includes those with disability; while, $44.0 \%$ did not know. Approximately, half of the participants $53.2 \%$ knew that special needs patients have health rights. More than half of the participants (56.7\%) knew that senility people have health rights; whereas, $36.1 \%$ did not know (Table 3).

Regarding perceptions of reproductive health rights, approximately $25.2 \%$ of the participants believed that abortion is completely forbidden in Islam; whereas, the majority $63.1 \%$ of them knew that abortion is allowed in exceptional cases. When asked about a woman's right to attain contraception, $25.7 \%$ responded that consent from a male guardian/partner is first required and $51.1 \%$ stated that the consent was not required. Further, $65.4 \%$ of the participants knew that screening includes human immunodeficiency virus (HIV) testing. Regarding HIV/acquired immunodeficiency syndrome (AIDS) patients in Saudi Arabia, 53.2\% knew that these patients have health rights; while, $41.0 \%$ did not know. Concerning sexual/reproductive information, $45.8 \%$ of the participants were knowledgeable of this; whereas, $35.9 \%$ were not aware about this (Table 4 ).

Majority the participants (74.3\%) agreed that disclosure of full information regarding their illness is a patient right, and most of them agreed (78.9\%) that newly diagnosed cancer patient must get full information about their disease. Most participants (75.6\%) also believed that a patient had the right to withhold information from his/ her family. About half of the participants (55.5\%) were knowledgeable that cancer patients in Saudi Arabia have the right to free medical treatment. About $52.2 \%$ of the participants responded that cancer patients have the right to free chemotherapy treatment. However, $49.6 \%$ of the participants also responded that cancer patients have the right to free radiotherapy treatment. Only half of the participants (52.9\%) knew that cancer patients have the right to free surgical treatment; whereas, $41.2 \%$ did not know about it (Table 5).

\section{Discussion}

The results of present study showed that participants have an acceptable knowledge regarding the rights of female patients. However, there is a lack of knowledge about the right of consenting herself for cesarean section, because they believed that female need a consent from a male guardian. Only few of the participants knew about such right (32.3\%); while, $46.1 \%$ knew that they can consent for herself. In contrast, study done in KAU on medical students found that the participants were not well informed generally about rights of female. However, a similar finding to the present study concerning the right of female to consent a caesarian section for herself showed that more than half of the students had poor knowledge [7]. The misconception that male guardian should be informed started to disappear due to the increased awareness of female rights, empowerment, and acknowledgment in Saudi Arabia [13].

Abortion is never allowed in Islam except in some exceptional cases, where it might threat the mother or the fetus. This decision should consider the gestational age at time of termination [14]. The results of the present study showed that understanding of the patients towards this right was satisfactory (63.1\%), as compared to another which showed that there is poor knowledge among medical students concerning abortion in Saudi Arabia [5]. It is assumed that participants in the present study has good knowledge due to including the abortion topic in the curriculum in medical colleges. 
Regarding HIV/AIDS patients' rights, $41.0 \%$ of participants failed to recognize that right. One third of the study participants were unknowledgeable of sexual/reproductive information. Previous study has also shown that the level of knowledge on sexual health among adolescents and youth in Saudi Arabia is poor [3]. It is not surprising that knowledge of sexual health rights among these students is especially low because the traditional Saudi culture discourages discussion of this subject. Half of the individuals with disabilities, special needs, and senility patients can comprehend about their rights. In contrast, more than one third do not know if they have rights. This is comparable to another study which concluded that almost half of the participants had knowledge about those rights [7]. This increase in knowledge is due to current curriculums mentioning a lot of scenarios about those vulnerable patients.

Concerning the rights of cancer patients in the present study, it is shown that $74.3 \%$ of participants understand that full disclosure of information is a patient's right, which is similar to the results of a study done on medical students in University of Dammam [4]. Majority of our participants (78.9\%) believed that the patient has the right to have full information to a newly diagnosed cancer. Most of the participants (75.6\%) agree that the patient has the right to hide this information from his/her family. Similar results were observed towards providing full information to a newly diagnosed cancer patient about his/her disease. However, half of the participant were knowledgeable, concerning the right of patient withholding information from their family [7].

Cancer patient's rights represent an essential part; therefore, medical ethics place a high value on providing truthful information to the patients. The results of present study have shown that half of the participants have positive knowledge about cancer patients' rights to free medical, chemotherapy, radiotherapy, and surgical treatment; whereas, more than one third of them do not know about such right. These results are in agreement with the previous study by Al-Amoudi et al [2]. The present study showed lack in knowledge in medical students concerning the rights of patients. However, some limitations of this study include participation of unequal number of students from the four colleges and no interns from recruited from KSAUHS.

\section{Conclusions}

The results of present study confirm that majority of the study participants had poor knowledge regarding the rights of female, reproductive, elderly, special needs, disabled, and cancer patients. Concerning the future doctors, it is important to transform and enhance knowledge of the existing laws and regulations considering the health rights of all patient groups for delivering optimal health care. Therefore, it is recommended that curriculum of medical colleges must include patients' health rights as a subject to improve the health outcomes of all medical students.

\section{List Of Abbreviations}

PBR Public Health Rights

ISNC Ibn Sina National College

BMC Batterjee Medical College

KAU King Abdul-Aziz University

KSAUHS King Saud bin Abdul-Aziz University

SPSS Statistical Package of Social Science

WHO World Health Organization

WFME World Federation for Medical Education

$\mathrm{MOH}$ Ministry of Health

DSFH IR Dr. Soliman Fakeeh Hospital Scientific Research Review Committee

HIV Human Immunodeficiency Virus

AID Acquired Immunodeficiency Syndrome

\section{Declarations}

\section{Ethics approval and consent to participate}

The approval was obtaining from Dr. Soliman Fakeeh Hospital Scientific Research Review Committee (DSFH IRB) with approval number: 95/IRB/2020. All methods were performed in accordance with the relevant guidelines and regulations. The authors approve their consent to publish. Written informed consent was obtained from all subjects or, if subjects were under 18, then from a parent and/or legal guardian.

\section{Availability of data and materials}

The data will be available for review from the corresponding author, on request.

\section{Informed Consent}


Informed consent was taken and institutional approval was obtained from Dr. Soliman Fakeeh Hospital Scientific Research Review Committee (DSFH IRB) with approval number: 95/IRB/2020. Written informed consent was obtained from all subjects or, if subjects were under 18 , then from a parent and/or legal guardian.

\section{Competing interests}

The authors declare no conflict of interest

\section{Funding}

This research received no funding.

\section{Authors' contributions}

HA conceptualized the manuscript and completed the first draft with ZN. HA, AA, SA, SE, SS, MB, MA and ZN assisted with information acquisition and interpretation; revised the manuscript; approved its final content; and agree to be personally accountable for their contributions.

\section{Acknowledgements}

This study was done during Research Summer School - Road of Change FCMS/2020

\section{Authors' information}

Heba K.Alshaeri email: hkalshaeri@fcms.edu.sa

Ali S. Al Qarni email: Alisalehalqarni@gmail.com

Shahad A. Alharbi email: Shad.har98@gmail.com

Safia M. El-Qaisi email: Soso_alqaisi@hotmail.com

Sarah A. Saif email: S.saif@hotmail.com

Muhannad H. Bin Sawad email: Muhannad.sawad@gmail.com

Maram M. Alharbi email: maramubark@gmail.com

Zuhair S. Natto, email: znatto@kau.edu.sa

\section{References}

1. Ducinskiene D, Vladickiene J, Kalediene R, Haapala I. Awareness and practice of patient's rights law in Lithuania. BMC Int Health Hum Rights. 2006;6:2-7. doi:10.1186/1472-698x-6-10

2. The Right to Health. 2020. Available from: https://www.ohchr.org/Documents/Publications/Factsheet31.pdf

3. Al Anazi BD, Faraj F, Al Balawi MM, Al Anazi MD. The awareness of patients' bill of rights among medical interns and medical students at Tabuk University. Open Access Maced J Med Sci. 2019;7:2932-9. doi:10.3889/oamjms.2019.785

4. Tay CS. Recent developments in informed consent: the basis of modern medical ethics. APLAR J Rheumatol. 2005;8:165-70. doi:10.1111/j.14798077.2005.00143.x

5. El-Sobkey SB, Almoajel AM, Al-Muammar MN. Knowledge and attitude of Saudi health professions' students regarding patient's bill of rights. Int J Heal Policy Manag. 2014;3:117-22. doi:10.15171/ijhpm.2014.73

6. Hosseini-Ghavam-Abad L, Asghari F, Bandehagh A, Najafipour S, Bigdeli S. Patient privacy: Awareness and attitudes of Iran University of Medical Sciences medical students. Med J Islam Repub Iran. 2019;33:12. doi:10.47176/mjiri.33.12

7. Al-Amoudi SM, Al-Harbi AA, Al-Sayegh NY, Eldeek BS, Kafy SM, Al-Ahwal MS, Bondagji NS. Health rights knowledge among medical school students at King Abdulaziz University, Jeddah, Saudi Arabia. Sherman JH, editor. PLoS One. 2017;12:e0176714. doi:10.1371/journal.pone.0176714

8. Galati AJ. Onward to 2030: sexual and reproductive health and rights in the context of the Sustainable Development Goals. 2015.

9. Mangin D, Stephen G, Bismah V, Risdon C. Making patient values visible in healthcare: A systematic review of tools to assess patient treatment priorities and preferences in the context of multimorbidity. BMJ Open. 2016;6:10903. doi:10.1136/bmjopen-2015-010903

10. Joolaee S, Nikbakht-Nasrabadi A, Parsa-Yekta Z, Tschudin V, Mansouri I. An Iranian perspective on patients' rights. Nurs Ethics. 2006;13:488-502. doi:10.1191/0969733006nej895oa

11. WHO. Patients' rights. 2010. Available from: https://www.who.int/genomics/public/patientrights/en/

12. Heidari A, Ahmadpour Z, GharehBoughlou Z. Patients and nurses awareness of patient's rights: A comparative study. Health, Spirituality and Medical Ethics. 2014;1:2-8. doi: 10.35301/ksme.2008.11.2.191

13. Alghamdi AM, Ahmed A. Women Empowerment in Saudi Arabia. 2018.

Page 5/8 
14. Kiong TW, Sakarai VN, Dissanayake N, Ravendaran ME. A Cross Sectional Study on the Awareness and Knowledge of Patient's Rights Among Medical Students in Malaysia. IJNSS. 2020;7:12-20. doi:10.21203/rs.3.rs-33352/v1

Tables

Table 1

Demographic Profile of the Participants

\begin{tabular}{|c|c|c|c|c|c|c|c|c|c|c|}
\hline \multirow{2}{*}{\multicolumn{2}{|c|}{$\begin{array}{l}\text { College } \\
\text { Gender }\end{array}$}} & \multicolumn{2}{|l|}{ KAU } & \multicolumn{2}{|l|}{ ISNC } & \multicolumn{2}{|l|}{ BMC } & \multicolumn{2}{|c|}{ KSAUHS } & \multirow{2}{*}{$\begin{array}{l}\text { Total } \\
393\end{array}$} \\
\hline & & Female & Male & Female & Male & Female & Male & Female & Male & \\
\hline & & 53 & 33 & 79 & 92 & 69 & 17 & 28 & 22 & \\
\hline \multicolumn{2}{|l|}{ Total } & \multicolumn{2}{|c|}{$86(21.8 \%)$} & \multicolumn{2}{|c|}{$171(43.5 \%)$} & \multicolumn{2}{|c|}{$86(21.8 \%)$} & \multicolumn{2}{|c|}{$50(12.7 \%)$} & \\
\hline \multicolumn{2}{|c|}{ Mean age of both gender } & \multicolumn{2}{|c|}{$21.56 \pm 1.78$} & \multicolumn{2}{|c|}{$23.07 \pm 1.64$} & \multicolumn{2}{|c|}{$21.81 \pm 2.003$} & \multicolumn{2}{|c|}{$21.16 \pm 1.16$} & $22.22 \pm 1.86$ \\
\hline \multirow[t]{6}{*}{ Academic Year } & $2 n d$ & 6 & 5 & 2 & 8 & 9 & 2 & 1 & 0 & $33(8.4 \%)$ \\
\hline & $3 r d$ & 10 & 20 & 2 & 5 & 10 & 5 & 3 & 5 & $60(15.3 \%)$ \\
\hline & 4th & 16 & 2 & 10 & 9 & 16 & 5 & 23 & 16 & 97 (24.7\%) \\
\hline & 5th & 4 & 0 & 19 & 24 & 12 & 2 & 1 & 1 & $63(16.0 \%)$ \\
\hline & 6th & 8 & 1 & 33 & 39 & 7 & 0 & 0 & 0 & $88(22.4 \%)$ \\
\hline & Intern & 9 & 5 & 13 & 7 & 15 & 3 & 0 & 0 & $52(13.2 \%)$ \\
\hline
\end{tabular}

King Abdulaziz University (KAU), Ibn Sina National College (ISNC), Batterjee Medical College (BMC), King Saud bin Abdulaziz University for Health Sciences

Table 2

Medical students' knowledge of the rights of female patients in Saudi Arabia

\begin{tabular}{|c|c|c|c|c|c|c|c|c|c|c|c|c|c|c|}
\hline Colleges & KAU & & & ISNC & & & BMC & & & KSAUH & & & All & \\
\hline Questions & Yes & No & $\begin{array}{l}\text { I do } \\
\text { not } \\
\text { know }\end{array}$ & Yes & No & $\begin{array}{l}\text { I do not } \\
\text { know }\end{array}$ & Yes & No & $\begin{array}{l}\text { I do } \\
\text { not } \\
\text { know }\end{array}$ & Yes & No & $\begin{array}{l}\text { I do } \\
\text { not } \\
\text { know }\end{array}$ & Yes & No \\
\hline $\begin{array}{l}\text { Do women } \\
\text { in SA } \\
\text { require a } \\
\text { male } \\
\text { guardian } \\
\text { to: Obtain } \\
\text { admission } \\
\text { to a } \\
\text { hospital }\end{array}$ & $\begin{array}{l}8 \\
(2.0 \%)\end{array}$ & $\begin{array}{l}67 \\
(17.0 \%)\end{array}$ & $\begin{array}{l}11 \\
(2.8 \%)\end{array}$ & $\begin{array}{l}19 \\
(4.8 \%)\end{array}$ & $\begin{array}{l}119 \\
(30.3 \%)\end{array}$ & $\begin{array}{l}33 \\
(8.4 \%)\end{array}$ & $\begin{array}{l}5 \\
(1.3 \%)\end{array}$ & $\begin{array}{l}62 \\
(15.8 \%)\end{array}$ & $\begin{array}{l}19 \\
(4.8 \%)\end{array}$ & $\begin{array}{l}2 \\
(0.5 \%)\end{array}$ & $\begin{array}{l}36 \\
(9.2 \%)\end{array}$ & $\begin{array}{l}12 \\
(3.1 \%)\end{array}$ & $\begin{array}{l}34 \\
(8.7 \%)\end{array}$ & $\begin{array}{l}284 \\
\left(72.3^{\prime}\right.\end{array}$ \\
\hline $\begin{array}{l}\text { Be } \\
\text { discharged } \\
\text { from the } \\
\text { hospital }\end{array}$ & $\begin{array}{l}11 \\
(2.8 \%)\end{array}$ & $\begin{array}{l}61 \\
(15.5 \%)\end{array}$ & $\begin{array}{l}14 \\
(3.6 \%)\end{array}$ & $\begin{array}{l}29 \\
(7.4 \%)\end{array}$ & $\begin{array}{l}110 \\
(28.0 \%)\end{array}$ & $\begin{array}{l}32 \\
(8.1 \%)\end{array}$ & $\begin{array}{l}7 \\
(1.8 \%)\end{array}$ & $\begin{array}{l}51 \\
(13.0 \%)\end{array}$ & $\begin{array}{l}28 \\
(7.1 \%)\end{array}$ & $\begin{array}{l}4 \\
(1.0 \%)\end{array}$ & $\begin{array}{l}34 \\
(8.7 \%)\end{array}$ & $\begin{array}{l}12 \\
(3.1 \%)\end{array}$ & $\begin{array}{l}51 \\
(13.0 \%)\end{array}$ & $\begin{array}{l}256 \\
\left(65.1^{\prime}\right.\end{array}$ \\
\hline $\begin{array}{l}\text { To sign } \\
\text { consent } \\
\text { for } \\
\text { medical } \\
\text { treatment }\end{array}$ & $\begin{array}{l}8 \\
(2.0 \%)\end{array}$ & $\begin{array}{l}69 \\
(17.6 \%)\end{array}$ & $\begin{array}{l}9 \\
(2.3 \%)\end{array}$ & $\begin{array}{l}24 \\
(6.1 \%)\end{array}$ & $\begin{array}{l}113 \\
(28.8 \%)\end{array}$ & $\begin{array}{l}34 \\
(8.7 \%)\end{array}$ & $\begin{array}{l}4 \\
(1.0 \%)\end{array}$ & $\begin{array}{l}59 \\
(15.0 \%)\end{array}$ & $\begin{array}{l}23 \\
(5.9 \%)\end{array}$ & $\begin{array}{l}3 \\
(0.8 \%)\end{array}$ & $\begin{array}{l}39 \\
(9.9 \%)\end{array}$ & $\begin{array}{l}8 \\
(2.0 \%)\end{array}$ & $\begin{array}{l}39 \\
(9.9 \%)\end{array}$ & $\begin{array}{l}280 \\
\left(71.2^{\prime}\right.\end{array}$ \\
\hline $\begin{array}{l}\text { To sign } \\
\text { consent } \\
\text { for surgery }\end{array}$ & $\begin{array}{l}16 \\
(4.1 \%)\end{array}$ & $\begin{array}{l}55 \\
(14.0 \%)\end{array}$ & $\begin{array}{l}15 \\
(3.8 \%)\end{array}$ & $\begin{array}{l}35 \\
(8.9 \%)\end{array}$ & $\begin{array}{l}102 \\
(26.0 \%)\end{array}$ & $\begin{array}{l}34 \\
(8.7 \%)\end{array}$ & $\begin{array}{l}11 \\
(2.8 \%)\end{array}$ & $\begin{array}{l}45 \\
(11.5 \%)\end{array}$ & $\begin{array}{l}30 \\
(7.6 \%)\end{array}$ & $\begin{array}{l}1 \\
(0.3 \%)\end{array}$ & $\begin{array}{l}36 \\
(9.2 \%)\end{array}$ & $\begin{array}{l}13 \\
(3.3 \%)\end{array}$ & $\begin{array}{l}63 \\
(16.0 \%)\end{array}$ & $\begin{array}{l}238 \\
\left(60.6^{\prime}\right.\end{array}$ \\
\hline $\begin{array}{l}\text { In SA, can } \\
\text { a woman } \\
\text { consent } \\
\text { for herself } \\
\text { for a } \\
\text { Caesarean } \\
\text { section? }\end{array}$ & $\begin{array}{l}43 \\
(10.9 \%)\end{array}$ & $\begin{array}{l}22 \\
(5.6 \%)\end{array}$ & $\begin{array}{l}21 \\
(5.3 \%)\end{array}$ & $\begin{array}{l}84 \\
(21.4 \%)\end{array}$ & $\begin{array}{l}34 \\
(8.7 \%)\end{array}$ & $\begin{array}{l}53 \\
(13.5 \%)\end{array}$ & $\begin{array}{l}29 \\
(7.4 \%)\end{array}$ & $\begin{array}{l}19 \\
(4.8 \%)\end{array}$ & $\begin{array}{l}38 \\
(9.7 \%)\end{array}$ & $\begin{array}{l}25 \\
(6.4 \%)\end{array}$ & $\begin{array}{l}10 \\
(2.5 \%)\end{array}$ & $\begin{array}{l}15 \\
(3.8 \%)\end{array}$ & $\begin{array}{l}181 \\
(46.1 \%)\end{array}$ & $\begin{array}{l}85 \\
\left(21.6^{\prime}\right.\end{array}$ \\
\hline
\end{tabular}


Table 3

Knowledge of medical students of the law and rights of patient with disabilities, special needs, and senility

\begin{tabular}{|c|c|c|c|c|c|c|c|c|c|c|c|c|c|c|}
\hline Colleges & KAU & & & ISNC & & & BMC & & & KSAUH & & & Total & \\
\hline Questions & Yes & No & $\begin{array}{l}\text { I do } \\
\text { not } \\
\text { know }\end{array}$ & Yes & No & $\begin{array}{l}\text { I do not } \\
\text { know }\end{array}$ & Yes & No & $\begin{array}{l}\text { I do } \\
\text { not } \\
\text { know }\end{array}$ & Yes & No & $\begin{array}{l}\text { I do } \\
\text { not } \\
\text { know }\end{array}$ & Yes & No \\
\hline $\begin{array}{l}\text { Does the } \\
\text { Saudi } \\
\text { Arabian } \\
\text { health } \\
\text { rights law } \\
\text { include: }\end{array}$ & $\begin{array}{l}48 \\
(12.2 \%)\end{array}$ & $\begin{array}{l}5 \\
(1.3 \%)\end{array}$ & $\begin{array}{l}33 \\
(8.4 \%)\end{array}$ & $\begin{array}{l}80 \\
(20.4 \%)\end{array}$ & $\begin{array}{l}11 \\
(2.8 \%)\end{array}$ & $\begin{array}{l}80 \\
(20.4 \%)\end{array}$ & $\begin{array}{l}49 \\
(12.5 \%)\end{array}$ & $\begin{array}{l}1 \\
(0.3 \%)\end{array}$ & $\begin{array}{l}36 \\
(9.2 \%)\end{array}$ & $\begin{array}{l}26 \\
(6.6 \%)\end{array}$ & $\begin{array}{l}0 \\
(0.0 \%)\end{array}$ & $\begin{array}{l}24 \\
(6.1 \%)\end{array}$ & $\begin{array}{l}203 \\
(51.7 \%)\end{array}$ & $\begin{array}{l}17 \\
(4.3 \%)\end{array}$ \\
\hline \multicolumn{15}{|l|}{$\begin{array}{l}\text { Those } \\
\text { with } \\
\text { disability? }\end{array}$} \\
\hline $\begin{array}{l}\text { Those } \\
\text { with } \\
\text { special } \\
\text { needs? }\end{array}$ & $\begin{array}{l}49 \\
(12.5 \%)\end{array}$ & $\begin{array}{l}5 \\
(1.3 \%)\end{array}$ & $\begin{array}{l}32 \\
(8.1 \%)\end{array}$ & $\begin{array}{l}88 \\
(22.4 \%)\end{array}$ & $\begin{array}{l}10 \\
(2.5 \%)\end{array}$ & $\begin{array}{l}73 \\
(18.6 \%)\end{array}$ & $\begin{array}{l}49 \\
(12.5 \%)\end{array}$ & $\begin{array}{l}3 \\
(0.8 \%)\end{array}$ & $\begin{array}{l}34 \\
(8.7 \%)\end{array}$ & $\begin{array}{l}23 \\
(5.9 \%)\end{array}$ & $\begin{array}{l}0 \\
(0.0 \%)\end{array}$ & $\begin{array}{l}27 \\
(6.9 \%)\end{array}$ & $\begin{array}{l}209 \\
(53.2 \%)\end{array}$ & $\begin{array}{l}18 \\
(4.6 \%)\end{array}$ \\
\hline $\begin{array}{l}\text { Those } \\
\text { with } \\
\text { senility } \\
\text { (elderly)? }\end{array}$ & $\begin{array}{l}54 \\
(13.7 \%)\end{array}$ & $\begin{array}{l}2 \\
(0.5 \%)\end{array}$ & $\begin{array}{l}30 \\
(7.6 \%)\end{array}$ & $\begin{array}{l}84 \\
(21.4 \%)\end{array}$ & $\begin{array}{l}19 \\
(4.8 \%)\end{array}$ & $\begin{array}{l}68 \\
(17.3 \%)\end{array}$ & $\begin{array}{l}57 \\
(14.5 \%)\end{array}$ & $\begin{array}{l}2 \\
(0.5 \%)\end{array}$ & $\begin{array}{l}27 \\
(6.9 \%)\end{array}$ & $\begin{array}{l}28 \\
(7.1 \%)\end{array}$ & $\begin{array}{l}5 \\
(1.3 \%)\end{array}$ & $\begin{array}{l}17 \\
(4.3 \%)\end{array}$ & $\begin{array}{l}223 \\
(56.7 \%)\end{array}$ & $\begin{array}{l}28 \\
(7.1 \%)\end{array}$ \\
\hline
\end{tabular}

Table 4

Medical students' knowledge of reproductive health rights in Saudi Arabia

\begin{tabular}{|c|c|c|c|c|c|c|c|c|c|c|c|c|c|}
\hline Colleges & KAU & & & ISNC & & & BMC & & & KSAUHS & & & To \\
\hline Questions & Yes & No & $\begin{array}{l}\text { I do not } \\
\text { know }\end{array}$ & Yes & No & $\begin{array}{l}\text { I do not } \\
\text { know }\end{array}$ & Yes & No & $\begin{array}{l}\text { I do not } \\
\text { know }\end{array}$ & Yes & No & $\begin{array}{l}\text { I do } \\
\text { not } \\
\text { know }\end{array}$ & Ye: \\
\hline $\begin{array}{l}\text { Abortion is never } \\
\text { allowed in Islam? }\end{array}$ & $\begin{array}{l}29 \\
(7.4 \%)\end{array}$ & $\begin{array}{l}50 \\
(12.7 \%)\end{array}$ & $\begin{array}{l}7 \\
(1.8 \%)\end{array}$ & $\begin{array}{l}46 \\
(11.7 \%)\end{array}$ & $\begin{array}{l}102 \\
(26.0 \%)\end{array}$ & $\begin{array}{l}23 \\
(5.9 \%)\end{array}$ & $\begin{array}{l}16 \\
(4.1 \%)\end{array}$ & $\begin{array}{l}59 \\
(15.0 \%)\end{array}$ & $\begin{array}{l}11 \\
(2.8 \%)\end{array}$ & $\begin{array}{l}8 \\
(2.0 \%)\end{array}$ & $\begin{array}{l}37 \\
(9.4 \%)\end{array}$ & $\begin{array}{l}5 \\
(1.3 \%)\end{array}$ & $\begin{array}{l}99 \\
(2 !\end{array}$ \\
\hline $\begin{array}{l}\text { Do they require a } \\
\text { male guardian to } \\
\text { obtain } \\
\text { contraception for } \\
\text { family planning? }\end{array}$ & $\begin{array}{l}32 \\
(8.1 \%)\end{array}$ & $\begin{array}{l}37 \\
(9.4 \%)\end{array}$ & $\begin{array}{l}17 \\
(4.3 \%)\end{array}$ & $\begin{array}{l}47 \\
(12.0 \%)\end{array}$ & $\begin{array}{l}93 \\
(23.7 \%)\end{array}$ & $\begin{array}{l}31 \\
(7.9 \%)\end{array}$ & $\begin{array}{l}16 \\
(4.1 \%)\end{array}$ & $\begin{array}{l}46 \\
(11.7 \%)\end{array}$ & $\begin{array}{l}24 \\
(6.1 \%)\end{array}$ & $\begin{array}{l}6 \\
(1.5 \%)\end{array}$ & $\begin{array}{l}25 \\
(6.4 \%)\end{array}$ & $\begin{array}{l}19 \\
(4.8 \%)\end{array}$ & $\begin{array}{l}10 \\
(2 !\end{array}$ \\
\hline $\begin{array}{l}\text { In Saudi Arabia, } \\
\text { does premarital } \\
\text { screening include } \\
\text { HIV testing? }\end{array}$ & $\begin{array}{l}51 \\
(13.0 \%)\end{array}$ & $\begin{array}{l}11 \\
(2.8 \%)\end{array}$ & $\begin{array}{l}24 \\
(6.1 \%)\end{array}$ & $\begin{array}{l}124 \\
(31.6 \%)\end{array}$ & $\begin{array}{l}19 \\
(4.8 \%)\end{array}$ & $\begin{array}{l}28 \\
(7.1 \%)\end{array}$ & $\begin{array}{l}44 \\
(11.2 \%)\end{array}$ & $\begin{array}{l}6 \\
(1.5 \%)\end{array}$ & $\begin{array}{l}36 \\
(9.2 \%)\end{array}$ & $\begin{array}{l}38 \\
(9.7 \%)\end{array}$ & $\begin{array}{l}5 \\
(1.3 \%)\end{array}$ & $\begin{array}{l}7 \\
(1.8 \%)\end{array}$ & $\begin{array}{l}25 \\
(6 !\end{array}$ \\
\hline $\begin{array}{l}\text { Are there any rights } \\
\text { for HIV/AIDS } \\
\text { patients in Saudi } \\
\text { Arabia? }\end{array}$ & $\begin{array}{l}38 \\
(9.7 \%)\end{array}$ & $\begin{array}{l}5 \\
(1.3 \%)\end{array}$ & $\begin{array}{l}43 \\
(10.9 \%)\end{array}$ & $\begin{array}{l}104 \\
(26.5 \%)\end{array}$ & $\begin{array}{l}12 \\
(3.1 \%)\end{array}$ & $\begin{array}{l}55 \\
(14.0 \%)\end{array}$ & $\begin{array}{l}25 \\
(6.4 \%)\end{array}$ & $\begin{array}{l}6 \\
(1.5 \%)\end{array}$ & $\begin{array}{l}55 \\
(14.0 \%)\end{array}$ & $\begin{array}{l}42 \\
(10.7 \%)\end{array}$ & $\begin{array}{l}0 \\
(0.0 \%)\end{array}$ & $\begin{array}{l}8 \\
(2.0 \%)\end{array}$ & $\begin{array}{l}20 \\
(5 i\end{array}$ \\
\hline $\begin{array}{l}\text { Is } \\
\text { sexual/reproductive } \\
\text { information taught } \\
\text { in Saudi Arabia? }\end{array}$ & $\begin{array}{l}42 \\
(10.7 \%)\end{array}$ & $\begin{array}{l}27 \\
(6.9 \%)\end{array}$ & $\begin{array}{l}17 \\
(4.3 \%)\end{array}$ & $\begin{array}{l}82 \\
(20.9 \%)\end{array}$ & $\begin{array}{l}64 \\
(16.3 \%)\end{array}$ & $\begin{array}{l}25 \\
(6.4 \%)\end{array}$ & $\begin{array}{l}33 \\
(8.4 \%)\end{array}$ & $\begin{array}{l}30 \\
(7.6 \%)\end{array}$ & $\begin{array}{l}23 \\
(5.9 \%)\end{array}$ & $\begin{array}{l}23 \\
(5.9 \%)\end{array}$ & $\begin{array}{l}20 \\
(5.1 \%)\end{array}$ & $\begin{array}{l}7 \\
(1.8 \%)\end{array}$ & $\begin{array}{l}18 \\
(4 !\end{array}$ \\
\hline
\end{tabular}


Table 5

Medical students' knowledge of the health rights of cancer patients in Saudi Arabia

\begin{tabular}{|c|c|c|c|c|c|c|c|c|c|c|c|c|c|c|}
\hline Colleges & KAU & & & ISNC & & & BMC & & & KSAUHS & & & Total & \\
\hline Questions & Yes & No & $\begin{array}{l}\text { I do } \\
\text { not } \\
\text { know }\end{array}$ & Yes & No & $\begin{array}{l}\text { I do not } \\
\text { know }\end{array}$ & Yes & No & $\begin{array}{l}\text { I do not } \\
\text { know }\end{array}$ & Yes & No & $\begin{array}{l}\text { I do } \\
\text { not } \\
\text { know }\end{array}$ & Yes & $\mathrm{Ni}$ \\
\hline $\begin{array}{l}\text { Is disclosure } \\
\text { of full } \\
\text { information } \\
\text { one of the } \\
\text { patient's } \\
\text { health rights? }\end{array}$ & $\begin{array}{l}63 \\
(16.0 \%)\end{array}$ & $\begin{array}{l}5 \\
(1.3 \%)\end{array}$ & $\begin{array}{l}18 \\
(4.6 \%)\end{array}$ & $\begin{array}{l}128 \\
(32.6 \%)\end{array}$ & $\begin{array}{l}16 \\
(4.1 \%)\end{array}$ & $\begin{array}{l}27( \\
6.9 \%)\end{array}$ & $\begin{array}{l}66 \\
(16.8 \%)\end{array}$ & $\begin{array}{l}9 \\
(2.3 \%)\end{array}$ & $\begin{array}{l}11 \\
(2.8 \%)\end{array}$ & $\begin{array}{l}35 \\
(8.9 \%)\end{array}$ & $\begin{array}{l}3 \\
(0.8 \%)\end{array}$ & $\begin{array}{l}12 \\
(3.1 \%)\end{array}$ & $\begin{array}{l}292 \\
(74.3 \%)\end{array}$ & $\begin{array}{l}3: \\
(8\end{array}$ \\
\hline $\begin{array}{l}\text { Do you agree } \\
\text { in providing } \\
\text { full } \\
\text { information to } \\
\text { a newly } \\
\text { diagnosed } \\
\text { cancer patient } \\
\text { about his/her } \\
\text { disease? }\end{array}$ & $\begin{array}{l}68 \\
(17.3 \%)\end{array}$ & $\begin{array}{l}10 \\
(2.5 \%)\end{array}$ & $\begin{array}{l}8 \\
(2.0 \%)\end{array}$ & $\begin{array}{l}137 \\
(34.9 \%)\end{array}$ & $\begin{array}{l}22 \\
(5.6 \%)\end{array}$ & $\begin{array}{l}12 \\
(3.1 \%)\end{array}$ & $\begin{array}{l}63 \\
(16.0 \%)\end{array}$ & $\begin{array}{l}15 \\
(3.8 \%)\end{array}$ & $\begin{array}{l}8 \\
(2.0 \%)\end{array}$ & $\begin{array}{l}42 \\
(10.7 \%)\end{array}$ & $\begin{array}{l}4 \\
(1.0 \%)\end{array}$ & $\begin{array}{l}4 \\
(1.0 \%)\end{array}$ & $\begin{array}{l}310 \\
(78.9 \%)\end{array}$ & $\begin{array}{l}51 \\
(1\end{array}$ \\
\hline $\begin{array}{l}\text { Does the } \\
\text { patient have } \\
\text { the right to } \\
\text { hide } \\
\text { information } \\
\text { from his } \\
\text { family? }\end{array}$ & $\begin{array}{l}71 \\
(18.1 \%)\end{array}$ & $\begin{array}{l}3 \\
(0.8 \%)\end{array}$ & $\begin{array}{l}12 \\
(3.1 \%)\end{array}$ & $\begin{array}{l}118 \\
(30.0 \%)\end{array}$ & $\begin{array}{l}26 \\
(6.6 \%)\end{array}$ & $\begin{array}{l}27 \\
(6.9 \%)\end{array}$ & $\begin{array}{l}64 \\
(16.3 \%)\end{array}$ & $\begin{array}{l}8 \\
(2.0 \%)\end{array}$ & $\begin{array}{l}14 \\
(3.6 \%)\end{array}$ & $\begin{array}{l}44 \\
(11.2 \%)\end{array}$ & $\begin{array}{l}0 \\
(0.0 \%)\end{array}$ & $\begin{array}{l}6 \\
(1.5 \%)\end{array}$ & $\begin{array}{l}297 \\
(75.6 \%)\end{array}$ & $\begin{array}{l}37 \\
(9\end{array}$ \\
\hline \multicolumn{15}{|c|}{ Do cancer patients in SA have the right to free } \\
\hline $\begin{array}{l}\text { Medical } \\
\text { treatment }\end{array}$ & $\begin{array}{l}55 \\
(14.0 \%)\end{array}$ & $\begin{array}{l}2 \\
(0.5 \%)\end{array}$ & $\begin{array}{l}29 \\
(7.4 \%)\end{array}$ & $\begin{array}{l}97 \\
(24.7 \%)\end{array}$ & $\begin{array}{l}16 \\
(4.1 \%)\end{array}$ & $\begin{array}{l}58 \\
(14.8 \%)\end{array}$ & $\begin{array}{l}33 \\
(8.4 \%)\end{array}$ & $\begin{array}{l}10 \\
(2.5 \%)\end{array}$ & $\begin{array}{l}43 \\
(10.9 \%)\end{array}$ & $\begin{array}{l}33 \\
(8.4 \%)\end{array}$ & $\begin{array}{l}0 \\
(0.0 \%)\end{array}$ & $\begin{array}{l}17 \\
(4.3 \%)\end{array}$ & $\begin{array}{l}218 \\
(55.5 \%)\end{array}$ & $\begin{array}{l}2 \varepsilon \\
(7\end{array}$ \\
\hline Chemotherapy & $\begin{array}{l}53 \\
(13.5 \%)\end{array}$ & $\begin{array}{l}4 \\
(1.0 \%)\end{array}$ & $\begin{array}{l}29 \\
(7.4 \%)\end{array}$ & $\begin{array}{l}88 \\
(22.4 \%)\end{array}$ & $\begin{array}{l}16 \\
(4.1 \%)\end{array}$ & $\begin{array}{l}67 \\
(17.0 \%)\end{array}$ & $\begin{array}{l}32 \\
(8.1 \%)\end{array}$ & $\begin{array}{l}6 \\
(1.5 \%)\end{array}$ & $\begin{array}{l}48 \\
(12.2 \%)\end{array}$ & $\begin{array}{l}32 \\
(8.1 \%)\end{array}$ & $\begin{array}{l}0 \\
(0.0 \%)\end{array}$ & $\begin{array}{l}18 \\
(4.6 \%)\end{array}$ & $\begin{array}{l}205 \\
(52.2 \%)\end{array}$ & $\begin{array}{l}26 \\
(6\end{array}$ \\
\hline Radiotherapy & $\begin{array}{l}48 \\
(12.2 \%)\end{array}$ & $\begin{array}{l}5 \\
(1.3 \%)\end{array}$ & $\begin{array}{l}33 \\
(8.4 \%)\end{array}$ & $\begin{array}{l}85 \\
(21.6 \%)\end{array}$ & $\begin{array}{l}13 \\
(3.3 \%)\end{array}$ & $\begin{array}{l}73 \\
(18.6 \%)\end{array}$ & $\begin{array}{l}32 \\
(8.1 \%)\end{array}$ & $\begin{array}{l}8 \\
(2.0 \%)\end{array}$ & $\begin{array}{l}46 \\
(11.7 \%)\end{array}$ & $\begin{array}{l}30 \\
(7.6 \%)\end{array}$ & $\begin{array}{l}2 \\
(0.5 \%)\end{array}$ & $\begin{array}{l}18 \\
(4.6 \%)\end{array}$ & $\begin{array}{l}195 \\
(49.6 \%)\end{array}$ & $\begin{array}{l}2 \varepsilon \\
(7\end{array}$ \\
\hline Surgery & $\begin{array}{l}52 \\
(13.2 \%)\end{array}$ & $\begin{array}{l}3 \\
(0.8 \%)\end{array}$ & $\begin{array}{l}31 \\
(7.9 \%)\end{array}$ & $\begin{array}{l}91 \\
(23.2 \%)\end{array}$ & $\begin{array}{l}14 \\
(3.6 \%)\end{array}$ & $\begin{array}{l}66 \\
(16.8 \%)\end{array}$ & $\begin{array}{l}33 \\
(8.4 \%)\end{array}$ & $\begin{array}{l}6 \\
(1.5 \%)\end{array}$ & $\begin{array}{l}47 \\
(12.0 \%)\end{array}$ & $\begin{array}{l}32 \\
(8.1 \%)\end{array}$ & $\begin{array}{l}0 \\
(0.0 \%)\end{array}$ & $\begin{array}{l}18 \\
(4.6 \%)\end{array}$ & $\begin{array}{l}208 \\
(52.9 \%)\end{array}$ & $\begin{array}{l}2 i \\
(5\end{array}$ \\
\hline
\end{tabular}

\section{Supplementary Files}

This is a list of supplementary files associated with this preprint. Click to download.

- STROBE.docx

- STROBE.docx

- SupplementaryFile.docx

- SupplementaryFile.docx 